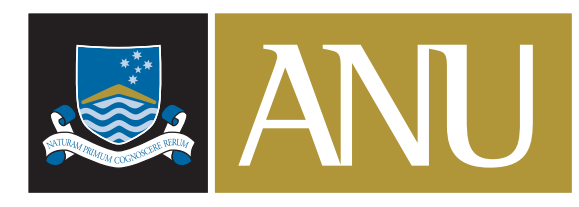

AUSTRALIA-JAPAN RESEARCH CENTRE

ANU COLLEGE OF ASIA \& THE PACIFIC

CRAWFORD SCHOOL OF ECONOMICS AND GOVERNMENT

\title{
BEYOND 'ASIAN VALUES': RATIONALES FOR AUSTRALIAN-JAPAN COOPERATION IN ASIAN REGIONALISM
}

Go Ito

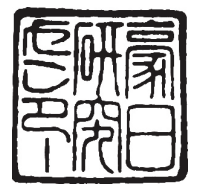

ASIA PACIFIC ECONOMIC PAPERS

No. 389, 2010 

ASIA PACIFIC ECONOMIC PAPER NO. 389

2010

\title{
BEYOND 'ASIAN VALUES': RATIONALES FOR AUSTRALIAN-JAPAN COOPERATION IN ASIAN REGIONALISM
}

Go Ito*

\author{
AUSTRALIA-JAPAN RESEARCH CENTRE \\ CRAWFORD SCHOOL OF ECONOMICS \& GOVERNMENT \\ ANU COLLEGE OF ASIA AND THE PACIFIC
}


(C) Go Iто, 2010.

This work is copyright. Apart from those uses which may be permitted under the Copyright Act 1968 as amended, no part may be reproduced by any process without written permission.

Asia Pacific Economic Papers are published under the direction of the Editorial Committee of the Australia-Japan Research Centre (AJRC). Members of the Editorial Committee are:

Professor Jenny Corbett

Executive Director

Australia-Japan Research Centre

The Australian National University, Canberra

Professor Emeritus Peter Drysdale

Crawford School of Economics and Government

The Australian National University, Canberra

Professor Christopher Findlay

Professor of Economics

University of Adelaide

Adelaide, South Australia

Professor Stuart Harris

Department of International Relations

The Australian National University, Canberra

Dr Kazuki Onji

Crawford School of Economics and Government

The Australian National University, Canberra

Papers submitted for publication in this series are subject to double-blind external review by two referees. The views expressed in APEPs are those of the individual authors and do not represent the views of the Australia-Japan Research Centre, the Crawford School, or the institutions to which authors are attached.

The Australia-Japan Research Centre is part of the Crawford School of Economics and Government, The Australian National University, Canberra.

ISSN 07288409

ISBN 978-0-86413-343-4

Australia-Japan Research Centre

Crawford School of Economics and Government

The Australian National University

CAnberra ACT 0200

Telephone: (61 2) 61253780

FACSIMILE: (61 2) 61258448

E-MAIL: AJRC@ANU.EDU.AU

URL: HTTP://WWW.CRAWFORD.ANU.EDU.AU 


\section{BEyond 'Asian VALUES':RATIONALES FOR Australian-Japan Cooperation in Asian REGIONALISM}

\section{Abstract}

In the past, the experience of the 'East Asian Miracle' and the sufferings from the 'East Asian Meltdown' were the impetus to generate and develop East Asian regional identity. The situation, however, is changing drastically. The future of East Asia regionalism has become amorphous because of complicated new trends. Japan, one of the important actors that constitute triangular relationships in East Asia, has been encouraging development of East Asian regionalism in the economic arena. Australia and Japan continue to work closely together in APEC, and are both founding members of the East Asia Summit. China's growing political presence in East Asia, particularly within ASEAN, and the emergence of new regional organisations after the Asian Financial Crisis meant that John Howard could not afford to ignore regional multilateral diplomacy, despite his preference for bilateralism. When the Labor Party took power in 2007, it continued the trend found in the late Howard administration towards regional multilateralism.

* The research for this article was undertaken while the author was the inaugural Australia-Japan Foundation Distinguished Visiting Fellow at the Australia-Japan Research Centre, Crawford d School of Economics and Government, Australian National University from March to September 2009.

** Professor of International Relations, Meiji University, Tokyo, Japan

\section{Australia-Japan Relations in Asian Regionalism}

The purpose of this paper is to examine the costs and benefits which both the Australian and the Japanese governments will receive in forming various regional institutions in the Asia-Pacific. More specifically, it will explore the possibility of Australia-Japan cooperation in the entire regional framework.

The term 'multilateralism' sounds as if it urges cooperation among countries. The greater the number of countries engaged in a policy issue, the more interests they tend to show in leading them into an agreement. In reality, however, the mission for international 
cooperation, as the number of the countries increases, becomes more difficult as more countries come to engage in multilateral negotiations. ${ }^{1}$

In fact, there are three conditions under which a state has positive interests in continuing to engage in multilateral negotiations. First, because multilateral negotiations have more actors involved in negotiations, states need to have more specific interests and benefits in multilateral negotiations than in bilateral meetings. Generally speaking, multilateral settings need more logistics than bilateral meetings, and if a government feels isolated from the other parties, there will be no incentives for it to participate in the multilateral gathering.

Second, actors in multilateral settings always pay attention to free-riding by others. In bilateral negotiations, there are fewer possibilities of free-riding, and more powerful states prefer to conduct bilateral negotiations while the less powerful are inclined to make use of established multilateral frameworks.

Finally, once multilateral institutions are established, their members pay attention to lessening management costs, but commit to sharing the costs of achieving the specific objectives of the institution. When it was created, APEC was the political institution by which Australia sought to include the United States. That is, it sought to cooperate with the US government and others including Japan to share the costs of 'open regionalism'.

For Australia, Japan is the largest buyer of its primary products, including agricultural and mining products. It is Australia's top market for a number of specific products as well: coal, LNG, beef, aluminium, copper, woodchips and dairy products. These are the industries on which much of regional and rural Australia relies.

By 2009, Australia's exports of goods and services to Japan reached $\$ 35.5$ billion, and represent a vital contribution to Australia's record total of $\$ 210$ billion in exports. Also, Japan is the third biggest foreign investor in Australia. Japanese investment provides thousands of jobs in the manufacturing sector in Victoria and South Australia. This is the reason why the Australian government has commenced negotiations on a bilateral Free Trade Agreement (FTA) with Japan.

Both governments believe they can deliver more opportunities for business through an FTA. For example, services account for more than two-thirds of our respective economies, but they are a relatively small part of our total trade. By addressing regulatory barriers and improving access, an FTA could help increase trade in this sector.

Thus, both governments affirmed their mutual goal of concluding an FTA that is comprehensive, WTO-consistent, delivers benefits to both sides, and is concluded through a single undertaking. Both also restated the agreement by the respective Prime Ministers that negotiations would begin with all products and issues, with options for flexibility on the table. In the following, I will delineate further the interests of Australia as well as Japan 
toward wider community building in the Asia-Pacific.

\section{Regional Frameworks}

Economic growth in Australia and Japan shows the benefits of the free flow of goods, services and investment between countries. Both Australia and Japan are much better off today because by and large both have been able to sell our goods freely to each other and on the world market.

We have seen incredible global economic growth for the past three decades. Australia and Japan are working together, regionally and multilaterally, to push for trade liberalisation. Figures put together by APEC show that per capita real GDP in APEC economies grew 26 per cent between 1989 and 2003, compared to only eight per cent in non-APEC economies.

It was the close cooperation of Australian and Japanese academics, business people and officials over some two decades that led to the eventual creation of the Asia-Pacific Economic Cooperation Forum (APEC) in Canberra in 1989. They recognised the potential for greater cooperation around the Pacific Rim. We can be pleased with the success of APEC and the vital contribution it is making to prosperity and community building in the Asia Pacific region.

Australia and Japan continue to work very closely together in APEC today. But we also think APEC can do more. Australia and Japan agree that we need to strengthen APEC as an institution. It needs a better-resourced secretariat and a capacity to undertake analytical work in support of its trade and economic agenda. Without more resources, APEC will struggle to deliver to its potential across its increasingly diverse agenda.

Japan and Australia are both founding members of the East Asia Summit. The EAS is still evolving, but it is already making an important contribution to regional relations and has developed a forward work program of practical activity. For instance, the EAS work on enhancing regional financial integration and cooperation has the potential to deliver tangible benefits to EAS members and contribute to East Asia's long-term stability and development.

Australia supports Japan's EAS proposal for a non-government study on a possible Comprehensive Economic Partnership in East Asia - essentially an FTA involving the 16 EAS member countries.

Beyond our immediate region, it is crucial that we continue to push for progress in the Doha Round of multilateral trade negotiations. Australia and Japan are both committed to a comprehensive outcome for the Doha Round. A multilateral round still offers the best way to get real improvements in market access for Australia's exports. Completing 
the Doha Round is also crucial to strengthening the global rules-based system, which has played such an important part in driving prosperity in both Australia and Japan. Australia and Japan agree on the principle that freer trade is good for everyone. We work closely together in the G6 - Australia, Japan plus the G4.

\section{Australia before Howard}

Historically, Australia viewed Asia as a source of threats; not as a region to be integrated with, but guarded against. In the first part of the twentieth century, Australia's fear of the 'north' mostly focused on Japan, and Australia looked to the power of the British Navy to protect them. The fall of Singapore in 1942 and differences with the British over the war however weakened the British-alliance link. As its dependence on the British faded, Australia looked to America at its next 'great and powerful friend'. In 1951, Australia had signed the ANZUS alliance with a reluctant United States, as essentially a quid pro quo for an easy peace treaty with Japan. Communist China increasingly became the focus for Australia.

Australia's first bid at regional organisation-building came in the 1960s with the Asian Pacific Council (ASPAC), an inter-governmental security body which excluded the PRC and aimed to keep the United States engaged. Foreign Minister Hasluck said, regarding Australia's role in the Asia Pacific Council or ASPAC, that 'We in Australia are in a position to be a bridge between the Asian and non-Asian. ${ }^{2}$ However, after the US opening to China (1971) and the subsequent US-China rapprochement, ASPAC disbanded; while in Australia regional multilateralism lost its significance and priority was placed on independent war-fighting ability. Yet Australia still desired a multilateral option for Asia, afraid of isolation. In 1981, Tony Street, Foreign Affairs Minister in the Liberal Fraser Administration, noted that 'Australia needs a foreign policy [to Asia] which encompasses not just bilateral relations but the multilateral diplomacy of international organisations and blocs'. 3

In 1983, Bob Hawke's Australian Labor Party (ALP) won power and put considerable emphasis on strengthening relations with the Asia Pacific. Hawke was trained as an economist and had worked as a trade union organiser. And he realised that Australia's economic future would lie in Asia, in particular Hawke held personal hopes for China. In 1988 Gareth Evans become Foreign Minister in the Hawke government, and one year later defined a multilateral/regional approach in a ministerial statement, Australia's Regional Security. Evans stated regional security should be multi-dimensional including 'immigration, education and training, cultural relations, information activities etc' under rubric of 'comprehensive engagement.' At the same time, the Garnaut Report, commissioned 
by the Australian Government from the academic Ross Garnaut, was released. Entitled Australia and Northeast Asian Ascendancy, it highlighted the importance of Northeast Asia to Australia, especially economically, and its call for liberalisation and integration of Asia into Asia was the trigger for Hawke's APEC proposal in Korea in 1989.

Australian diplomats, such as Richard Woolcott ${ }^{4}$, cooperated closely with Japan to form this body, and to guide it to an 'open regionalism' which would include the United States. In fact, APEC stands out as the ALP's greatest foreign policy achievement in Asia. APEC served Australia's interests in three ways; firstly, to keep the United States politically engaged in Asia, second to prevent the formation of a three-bloc world (which Australia would be excluded from) and thirdly to shore up the flagging World Trade Organisation Uruguay Round. ${ }^{5}$ The APEC process was made even more significant to Australia in 1993, when US President Clinton proposed a leaders' forum. APEC became an ideal venue for Australian diplomacy, gathering together leaders of all the countries important to Australia in one place. ${ }^{6}$

In 1991, Keating became Prime Minister and promised an even deeper engagement with Asia. In both the Strategic Review 1993, and Defending Australia: Defence White Paper 1994 paid attention to regional organisations. The Review discusses this issue in terms of 'regional security community', encouraging 'countries of the region to recognise the interests they share and ways they might cooperate to support them'.

In 1994, the ASEAN Regional Forum was formed. Compared to APEC, Australia played a small role in its creation, but it fitted well with Australia's expectations, indeed as early as 1990 when Foreign Minister Evans had argued for a regional security organisation. Keating also tried to position Australia closer to Asia culturally, lobbying the United States on behalf of Indonesia about human rights and even claiming, at the height of the Asian values debate in 1995, that Australian values like 'mateship' were equivalent to Asian communitarian values.?

By the end of the ALP term in power in 1996, Australia's foreign policy could be characterised as so-called 'middle power diplomacy'. Australia was interested chiefly in maintaining its overall position in the regional order, even as power relationships within Northeast Asia or the ASEAN had entered a state of flux. To do so, Australia had enlisted the assistance of multilateral institution building at the regional level. Multilateral regionalism allowed Australia to achieve its interests in stability and the status quo by involving the United States and by maintaining a good distance from both Japan and China by submerging them in a larger group. Thus, Australia's foreign policy was, despite its innovations in multilateralism, quite conservative in its goals. Indeed, Evans admits his 'middle power diplomacy' was 'ultimately no less self-interested than any other kind'. 8 
Asia Pacific Economic Papers

\section{Howard's Bilateralism and 'Middle Power Diplomacy'}

It has been said that the Howard Liberal administration turned to bilateralism in style. However, this section argues that Howard's interest in regional stability stayed the same. It will examine the external and internal factors which pushed Howard's Australia first to bilateralism and then returned it to multilateralism.

\section{(1) Outputs: War on Terror and the East Asian Summit}

When Howard came to power in March 1996, he promised a non-ideological, hard-headed approach to Asia based on national interests and an acknowledgement of some essential differences between Asia and Australia and a 'rebalancing' of Australian relations towards the United States. However, exactly how to relate the Liberal Party foreign policy agenda to the dominant middle-power strategy which the ALP had developed was uncertain. Foreign Minister Alexander Downer's first speeches were rehashes of ALP 'middle-power-ism' without that name, being positive about regional organisations like the ARF and asserting Australia's commitment to the region. ${ }^{9}$ The Howard administration's first foreign policy White Paper, In the National Interest, was released in 1997. In it the Howard administration conceived of Australian foreign policy as follows: 'Key components of Australia's regional security strategy...[are] a strong national defence capability, the security alliance with the United States, developing bilateral defence and security relationship with the countries throughout the Asia-Pacific, and strengthening multilateral security links in the region, especially the ASEAN Regional Forum'. And it advocated, 'a multi-faceted approach... [based on] complementing Australia's national defence capability, bilateral security arrangement and regional defence cooperation with an active Australian role in fostering regional integration an shaping the regional security institutions which are emerging in the Asia-Pacific.' 10

At first it seemed, however, as if Howard would continue the middle-power tradition of multilateralism but with more role for the United States. Indeed, after just one month in office, the 1996 Taiwan Straits crisis occurred. Howard called for restraint from China, and vocally supported the US decision to send the aircraft carrier Independence to the area. He also proposed that APEC be used to mediate, revealing his (mistaken) belief that the organisation could play a valuable role in regional security. ${ }^{11}$ The same year, Australia was excluded from the Asia-Europe Meeting or ASEM, as some in Asia felt Australia would be a proxy for US interests if invited to the forum. The reputation recognising Howard as anti-Asian strengthened when later in that year Howard and Clinton issued the Sydney Statement, a largely symbolic joint Security Declaration which nevertheless implied Australia would coordinate with the United States in future, presumably in Asia. ${ }^{12}$ 
Then, the advent of the Asian Financial Crisis in 1997 gave Howard a chance to respond to Asia on his own terms. And the Government offered USD1.0 billion each to Korea, Thailand, Indonesia, as Downer said 'showed ourselves to be all-weather friends in Asia, not just fair weather friends'. Moreover, Howard interceded with the United States on Indonesia's behalf for a more lenient IMF policy; although to no avail. ${ }^{13}$

Howard also had to face the disintegration of the fragile situation in East Timor, a problem which threatened relations with Australia's most strategically important partner Indonesia, the country which as de facto leader of ASEAN was also Australia's ticket to wider regional acceptance.

East Timor found itself holding a plebiscite on future independence even as antiindependence/pro-Indonesia militia were attempting to use force to control the result. With blood flowing, Australia pressed for a UN Peace-keeping operation; however Indonesia was steadfastly opposed to such a measure on its territory. Despite the fact that Australia had withheld intelligence from the United States about the extent of Indonesian involvement in the growing massacre in East Timor to protect the relationship with Indonesia (fearing increased US pressure on Indonesia's human rights), Howard succeeded in convincing President Clinton to provide US diplomatic support for a UN operation.

Facing pressure from the United States, Indonesia relented and allowed UN forces in. ${ }^{14}$ The United States provided over-the-horizon support for Australia's Navy, which was dispatched to East Timor. Tensions ran high between Australia and Indonesia, and in the early stages the possibility of limited conflict existed. Howard's close coordination with the Americans had allowed Australia to get its way. In the light of these events, one journalist categorised Australia's role as 'deputy sheriff'. Howard did not deny this, and succeeded in upsetting further regional players. ${ }^{15}$ There was a price to pay for Australia's 'interference' in Indonesia, with the AFTA-CER negotiations being downgraded at the ASEAN Summit in Chiang Mai in 2000.

However, East Timor and Howard's growing bilateralism did not entail the abandonment of Australia's basic interest, which was the preservation of its place in a stable regional order. Nor indeed did it entail abandonment of regional organisations as a means to achieve that interest. Foreign Minister Downer noted that Australia still needed the ARF to 'develop in ways that parallel our strategic interests, not only by providing a mechanism for fostering regional peace and stability, but also by reinforcing linkages between the United States and East Asia, engaging China in constructive ways, and providing opportunities for Japan to play a more active role on regional security issues.' ${ }^{16}$ But the worsening of Australia's relations with Indonesia, and with ASEAN more generally, was making it increasingly difficult to satisfy Australia's interest in a stable regional order.

Australian support for the 'War on Terror' further risked Australia's relations with 
Asia, in particular Indonesia - a predominately Muslim country. Australia's support for America in both the Afghan and Iraq operations 'confirmed' suspicions in Asia that Australia was a merely a forerunner for American interests in the region, a situation not helped by the then US Defence Secretary. ${ }^{17}$ The political relationship spilled into economic and strategic areas, as Australia also moved to sign an FTA with the United States and negotiated highest access to intelligence with the United States under the four-eyes program (United States, Canada, United Kingdom, and Australia). Most egregiously of all, Howard suggested in 2002 that Australia also had a right to pre-emptive self-defence in the region, presumably a right to cross into Indonesia and kill Indonesians suspected as terrorists. ${ }^{18}$ Of course, as the Indonesian President said, this would be war.

At the same time Australia's increasing ambivalence to regional multilateral solutions for security after 9-11 can be seen in the update to Australia's National Security (released 2003, to update the pre-911 version). Neither ASEAN nor the ARF was mentioned even once in this document, the first time since the ARF had come into existence. ${ }^{19}$ Accordingly the 2003 White Paper, Advancing the National Interest, notes that 'Australia depends on the strength of its bilateral relations around the world to advance its national interests. The greater part of the day-to-day work of Australia's foreign and trade policy is bilateral advocacy — working to influence governments and others to take decision that suit Australia's as well as their own interests. ${ }^{20}$

Howard pursued closer bilateral defence and security ties with Indonesia, Japan and India but not with China leading to concerns from China. On 13 November 2006 Howard signed the Lombok treat with Indonesia, which restored and expanded the agreement that the ALP had signed in 1995, and also in 2006 raised with India concluding an export agreement for uranium outside of the NPT. Together with India, Japan and the United States, Australia took part in a Quadrilateral naval exercise in Bay of Bengal in September 2007, a spin off from quadrilateral talks. ${ }^{21}$ In March of 2007, Howard signed a bilateral security cooperation with Japan and joined tri-party talks with the United States, Japan's only second such defence agreement. But it is more a diplomatic alliance than military, noting issues like UNSC reform. Such cooperation with China was not envisaged (including in the US defence update 2007). Yet, as John Howard himself notes, Howard visited China more than any other country, and the simultaneous visits to Canberra by Presidents Bush and $\mathrm{Hu}$ in 2003 he viewed as a regional coup of bilateralism (although some Members of Parliament turned their backs on President $\mathrm{Hu}$, and some media ridiculed the Bush visit as a sleep-over). ${ }^{22}$ However, he could not play middle power role, as he was asked by Bush for Australia to intercede with China on North Korea, and duly passed on the message, but received a non-committal answer, that is with no value-added. ${ }^{23}$

On the economic front, Howard's bilateral approach to Asia also saw Australia negoti- 
ate FTAs with Singapore in 2003 and Thailand 2005, and importantly to start negotiations with China and Japan. Indeed, China and Japan have become locked into concluding an FTA with Australia, a game played in part for access to Australia's natural resources and also for strategic reasons. In 2003 Australia signed a deal to provide China (Hong Kong and Shenzhen) with many tons of LNG, worth US\$25 billion. Moreover, Howard linked the diplomatic effort devoted to China in the FTA to a Chinese expression of support for Australia in the EAS summit. Some believe, 'Australia began a re-engineering of its 'entry' into Asia, this time through the door of bilateralism. ${ }^{24}$

However, there are two outstanding pieces of apparent multilateralism: the 2004 Bali Conference and 2005 EAS. In October of 2002, a terrorist suicide-bombing attack in a nightclub at Bali killed 202 people, of whom 88 were Australian. The Bali conference was organised by Australia bureaucrats for a regional counter-terrorism effort, as the prime ministerial level was considered too political. On the issue of terrorism, 2004 saw two foreign policy reports released both of which discussed the role of ASEAN, ARF and APEC as important, but most attention paid to bilateral Indonesia-Australia ties(particularly, the Jakarta Centre for Law Enforcement Cooperation) . But Australia also co-hosted the Regional Ministerial Meeting on counter-terrorism in Bali in February 2004 and signed the ASEAN-Australia Joint Declaration for cooperation to combat international terrorism on 1 July 2004 showing a regionalist bent. Australia also joined the Proliferation Security Initiative (PSI) along with other Asian countries. ${ }^{25}$ After the Bali conference, we also saw 12 individual bilateral memoranda signed, serving Australia's functional interest through bilateralism. ${ }^{26}$

The other regional group Australia joined rather than instigated, and not without some pain, was the EAS. At the Vientiane Summit (2004) it was clear that for ASEAN having Australia join would be good and even the Malaysian Prime Minister had publicly noted that Australia could be invited to the EAS. Howard however said that the Treaty of Amity and Cooperation (TAC) has certain meaning within ASEAN and that 'it was not appropriate to sign it'. In December 2002, Howard's 'pre-emptive doctrine' committed Australia in extremis to intervention so it could not sign the TAC then. The TAC calls for non-interference in internal affairs, troublesome with Indonesia/West Papua. In early April 2005, Prime Minister Badawi downplayed the pre-emption issue and behind the scenes invited Australia to attend the EAS, but still Howard seemed hesitant, referring to the TAC as 'of a mindset we have all moved on from'. After Downer acknowledged the need for Australia to join the EAS, in April 2005, ASEAN foreign ministers acted to clarify the criteria for entry into EAS (substantive relations, full Dialogue Partner status, and signature of the TAC). Korea joins and on 28 July 2005, the Australia-ASEAN communiqué announced Australia's intention to join TAC, and Australia eventually signed 
the TAC and joined the EAS.

In fact during the Howard years, Australia distanced itself from condemning China's human rights violations, and was from early on a supporter of China's early accession to the WTO, and also refused to join Washington to lobby the EU to maintain the Arms Control Weapons Sales rules in relation to China.

\section{(2) Internal Factors: An Unintended Cooperation between White Australians and Factory Workers}

What are the internal factors which have pushed Howard to pursue Australia's presence in Asia, although via moving away from regional organisations and support for the United States. It should be noted that Howard, despite his reputation as not being interested in foreign policy, became increasingly interested in it as time passed. Howard's personal political thought he traces to the paragon of conservative thinking, Edmund Burke. ${ }^{27}$ Like Burke (who railed against the British East India Company's contempt for Indian customs), while Howard initially stressed respect for the values in the various Asian countries and their right to choose whatever political system they wished, a very ASEAN friendly view. ${ }^{28}$

Although he believed Western values to be superior, during the crisis Howard declared Australia to be the strong man of Asia now, a statement designed for domestic consumption, but highly sensitive regional neighbours took affront. ${ }^{29}$ The events of 11 September 2001 affected Howard personally, since he was actually in Washington on the 10 September. John Howard addressed a joint session of the US Congress on 12 September, and was greeted with enthusiasm as he invoked the ANZUS alliance.

Additionally, managing relations with Asia became a political football by the mid1990s. Australia's success in forming APEC and the emergence of the ARF as a 'new' pillar for security had made the ALP become champion for a comprehensive engagement with Asia, especially under Keating. Paul Keating was an odd man to come to Asia, being a lover of all things Western. But Keating came to advocate integration into Asia in cultural terms rather than just trade - a shared destiny with Asia. ${ }^{30}$ In fact by the end of his term in 1995-6, the ALP had gone all 'regional.' At the height of the Asian Values debate, about who was in and out of the region, Keating claimed the Australian value of 'Mateship' is compatible with Asian values ${ }^{31}$, and Foreign Minister Evans described an 'East Asian Hemisphere'. Neither idea was accepted in the region. ${ }^{32}$

However, his tilt away from Asia in part came from his reading of the Australian domestic political landscape. He came to power on the back of the so-called 'Howard's Battlers', a group of aspirational/'moral' working class voters, which had traditionally voted ALP, but were leery of Asia (taking jobs) and the ALP's pro-Asian regionalism. However, Howard was not the only one which came to power on this wave; Pauline 
Hanson (a dis-endorsed liberal candidate) also won a seat in the House of Representatives in 1996. And in 1998 her party (One Nation) won a senate seat, challenging the Coalition by competing with the right-wing national party. One Nation was without a doubt motivated by the basest of racism, was overtly anti-Asian, anti-immigration and Howard did not move strongly against them in part because they were an expression of values of the Aussie Battler. In fact despite his weak showing the 1998 election, Howard was able to win the 2001 election on at nasty piece of anti-immigration policy called the 'Pacific Solution'33 and the 'Children Overboard' scandal.

There was also a domestic political reason for Howard's hesitance to sign the TAC and thereby join the EAS. Part of his criticism of the Keating administration was that Keating had entered into agreements (particularly the Indonesia Agreement on Maintaining Security 1995) without due oversight and in secrecy. Howard had set up the Joint Standing Committee on Treaties (JSCOT) on assuming office to stop this 'abuse', but in order to join the EAS at late notice he would have to sign the TAC without putting the matter before this very body for national interest evaluation. The submission to national interest evaluation of the JSCOT contained insistence that the TAC would not be inconsistent with Australia's treaty commitments including on security matters such as ANZUS and Five Power. It would not limit rights and responsibilities within the UN, (article 51 on self help included). ${ }^{34}$ Howard's desire to get this stamp of approval thereby affected the speediness of this accession. And of course criticism came from the right wing of his party, one commentator noting, signing the 'TAC is the post-modern equivalent of the Qing dynasty kowtow' 35

\section{(3) External Factors: Great power rebalancing}

However, these internal factors can only explain so much. To understand why Howard turned to bilateral approach to Asia, one needs to look at the external factors. In fact, Howard learnt a lot about the limits of regional organisations during his first term in office, lessons which reinforced his personal ideological position about the preference of bilateralism.

Howard came into a period in which APEC, the legacy of the ALP for which was a poster-boy for nearly a decade, was faced by many hard challenges. Howard had proposed APEC be used to mediate the Taiwan Straits crises, which earned him mocking laugher from the ALP, and the upset it caused China nearly cost Howard his closest political ally, Foreign Minister Downer. ${ }^{36}$ And by late 1996, Howard became aware that Australia's interest in trade liberalisation (via the Early Voluntary Sectoral Liberalisation or EVSL process) was not being furthered through APEC because of a 'split' between East and West, that is Japan (with Asia) and the United States (including Australia). This 'split' was again on display during the Financial Crisis in 1997-8, in which APEC achieved nothing 
of worth and Australia had to engage in alternative, bilateral efforts. ${ }^{37}$ At the same time, ASEAN, the centre of regionalism efforts, was unable to deal with even the minor issue of 'the Haze' from Indonesia's forest fires, which also reached some of the northern parts of Australia. Moreover, ASEAN membership expanded to include the authoritarian states of Indo-China. In fact, all of the ALP's much vaunted regional organisations were failing.

After learning the hard limits of regional organisations, Howard's next lesson was the utility of bilateral relations. The ARF, after having produced a promising concept paper on preventive diplomacy a few years earlier, dashed Australian hopes as the East Timor crisis unfolded in 1999. Howard learnt that only the might of the United States could give Australia the diplomatic leverage necessary to have UN peace-keepers allowed into Indonesia to stop the bloody violence. Moreover, in addition to reliance of the bilateral relationship with the United States, Howard noted that Australia's alliance half-brother, Japan, played a vital role in ensuring the success of the operation by organising the first donor meeting for reconstruction and despatching a Japan Self Defence Force contingent to the UN's INTERFET mission. ${ }^{38}$ Moreover, the other alliance half-brother, Korea's Kim Dae-Jung, also supported the INTERFET mission, arguably turning the diplomatic tide and starting a chain-reaction of offers of UN mission help from ASEAN, unusually even China unusually contributed civilian police. All this was achieved by bilateral means, a lesson Howard took home.

However China's growing political presence in East Asia, particularly within ASEAN, and the emergence of new regional organisations after the Financial Crisis meant that Howard could not afford to ignore regional multilateral diplomacy. Specifically, the ASEAN Plus Three process was engaging in creating a new regional trade and financial order based on a network of FTAs and the Chiang Mai Initiative; both of which Australia was excluded from. Howard's initial hesitance to join the East Asian Summit was due to a belief, shared widely, that Australia was only being invited to off-set China's influence in the body, a role Australia would prefer not to have to play. However, not becoming involved in such an East Asian body at this time could carry high costs in the future. Moreover, while the United States was not a member at this time, that option was not foreclosed. In fact, America's predominate presence in the region's security structure meant that the EAS was hardly going to undermine that order any time soon, a fact underlined by America's ready acceptance of the group. In fact, Australia was given reassurances that the EAS (and the TAC) would not interfere in any way with the operation of ANZUS, it seems reasonable to say that the EAS in fact supports the US-led security order in East Asia. Thus despite Howard's personal preference for Asian regionalism to remain at the level of a network of bilaterals, strategically there was no other option but to accede. As journalist Paul Kelly notes: 'By a singular irony, John Howard is being driven into signing a treaty that he 
No. 389,2010

doesn't like in order to join an East Asian summit that he pretends is unimportant. ${ }^{39}$

\section{The Return of the ALP, and Kevin Rudd's Return to Asian Multilateralism?}

The Labor Party came back to power in 2007. The Kevin Rudd ALP continued the trend found in the late Howard administration towards regional multilateralism. Australia's interest in regional multilateral is high for the same external reasons as in Howard administration, but Rudd's particular personality has pushed Australia's interest in regional multilateral even further.

\section{(1) Outputs: The 'Architecture proposal' and Head of State diplomacy}

Upon attaining office, Rudd moved quickly to undo some of the elements of the Howard bilateral relations which he believed most likely to entangle Australian in an Asian great game. Most dangerous of these agreements was the promise for Australia to sell uranium to India, ostensibly for peaceful energy reasons. In fact, with India's 1998 explosion of nuclear device, selling uranium to India looked like a high-stakes game of balancing against China, and in fact China had repeatedly questioned Australia's motives. While in opposition, Rudd had signalled that he opposed the selling of uranium to India outside of the Non Proliferation Treaty. And in January 2008, he dispatched his new foreign minister to meet with Indian Special Envoy Shyam Saran to communicate the bad news. Fortunately for Australia, the so-called 123 agreement was still held up at the Indian end and so Australia's unilateral ending of the agreement came at little political cost. Moreover, with conservative clique of Bush, Howard and Abe out of office, the quadrilateral group was coming apart as India looked to reposition itself closer to China (Prime Minister Singh visiting Beijing). Later Australia effectively ended the Quad talks completely, with Foreign Minister Smith proposing the end to the Japan-Australia-India trilateral talks. ${ }^{40}$

In March, Rudd left Australia for an 18-day world tour of head of state diplomacy. Rudd first visited the United States, where he drew down the Iraq deployment of troops but maintained the relationship, meeting with both presidential candidates and launching a bid for a United Nation's Security Council in New York. Next to Europe, then to China where he first impressed the Chinese with his Mandarin skills then shocked by calling 'as a true friend speaking directly' for Chinese leadership to meet with the Dalai Lama to resolve the Tibet problem. At the same time a row over Chinese investment in Australia natural resources was going on and the China-Australia FTA had stalled. Noticeable by its absence was a visit to Japan as part of the trip. In fact Rudd was questioned by a Japanese journalist at the UN about the lack of a visit to Japan, who also highlighted the absence 
of telephone conversations between the two new prime ministers. Coming as it did on top of the earlier rejection of quadrilateral thinking, and an emergent political problem between the two over whaling, it looked as if Rudd might be trying to cut away from Japan in favour of China. These fears seemed confirmed when Chinese Premier Wen Jiabao could not resist drawing attention to his own post-election telephone conversation with the new Australian Prime Minister.

Somewhat artificially, Rudd moved forward his schedule and flew to Japan in June; showing an awareness that Australian interests were not served by favouring only two of the great powers in north Asia. ${ }^{41}$ In fact, Rudd's meeting led to the activation of an Australian-Japanese diplomatic push along the nuclear non-proliferation and disarmament front was finally unveiled, with Gareth Evans as Australian co-chair and Kawaguchi Yoriko as co-chair for Japan; the first meeting of which was in October in Sydney in the same year.

On 4 June 2008, Rudd addressed the Asia Society of Australasia in Sydney. In a speech entitled 'It's Time to Build an Asia Pacific Community', Prime Minister Kevin Rudd proposed a regional architecture for the wider Asia Pacific region in which he emphasised regional institutions in underpinning 'an open, peaceful, stable, prosperous and sustainable region.' Rudd's vision specifically calls in the great power of the region, stating membership for United States, Japan, China, India, Indonesia (and of course Australia) and which is capable of 'full spectrum of dialogue...included security.' A so-called Concert of Asia. While sounding radical, in fact Rudd is just making official offer for what has been discussed at Track II. ${ }^{42}$

In fact, Rudd's bilateral head of state diplomacy won him praise in Australia. Fullilove notes most importantly the subtle move on both the United States and China whereby these bilateral relationships were solidified even as Canberra established a degree of independence from them, it was at least arguable that Rudd was delivering in precisely those areas where Howard had fallen short. ${ }^{43}$ But on the other hand the multilateral Asia Pacific Community has been criticised as an on-the-fly piece. Certainly, key regional players were not positive about the proposal when sounded out, and it was greeted with a deafening silence in the region that betrayed the lack of prospects of this idea. ${ }^{44}$ Rudd has since tried to rework the idea. At the Shangri-La Dialogue held in Singapore in May 2009, Rudd accepted that working with the existing (ASEAN-led) bodies, particularly the East Asia Summit was necessary. ${ }^{45} \mathrm{He}$ also called for a track 1.5 meeting to be held in Australia later in the year to discuss the proposal further. Unfortunately, it looks as if the APC idea has already weakened through contacts with ASEAN. Similar to APEC and the Japanese EAc, where the $\mathrm{C}$ was to stand for Community (rather than Cooperation), the APC has been watered down to an APc - implying a lack of institutionalisation and even Rudd's expectations for the timing of the enterprise have been pushed back to $2020 .{ }^{46}$ 
Yet Rudd has not turned his back on other means to build up Australia's presence. In the context of the East Asia regionalism, Rudd wasted no time in sign into law the ASEAN-Australia and New Zealand Free Trade Area, the negotiation of which had been broken off in 1999 and only restarted in 2008 after Howard. In the same context, Rudd also joined in March of 2009 a FTA and entered a Joint Security agreement with South Korea. ${ }^{47}$ Moreover, the Rudd Government new Defence White Paper, released in May 2009, foreshadows a significant increase in Australia's military power, in particular the decision to purchase 12 new submarines. Interestingly, the Defence White Paper does not mention any regional security organisations which Australia hopes will provide cooperative security, unlike the similar documents that the ALP had produced in their previous term.

\section{(2) Internal factors: Domestic politics, ideology,}

Rudd has comes from the same right-wing faction within the ALP as Hawke and Keating. Moreover, Rudd has clearly studied and approves of the middle-power strategy, making repeated reference to it, such as the 'creative middle-power diplomacy'. It is clear that Rudd is trying to complete the work of Hawke-Keating after the 11 -year hiatus. Indeed, Rudd chose Richard Woolcott as the diplomat instrumental in the formation of the 1989 APEC consensus to head his Asian plan. Rudd even said, 'Woolcott is to continue and hopefully complete the work he began on Prime Minister Hawke's behalf 20 years ago'. ${ }^{4}$ But that said, Rudd's plans have been criticised by Keating, and former Foreign Minister Evans was never consulted prior to the announcement.

Compared to Howard, Rudd emphasised Asia much more. This is based presumably on both his study of Asia at university and subsequent professional career as a diplomat in Beijing. These experiences have prompted some fears that Rudd might favour China, over perhaps Japan. In fact, at the Brookings Institution on 31 March, Prime Minister Rudd suggested China and Australia should be encouraged to be 'allies' in region. Rudd demonstrated a greater interest in foreign affairs, and has gained more control over foreign policy than perhaps any other previous prime minister. Indeed, his decision to appoint Stephen Smith, a competent but low-key player, to the Foreign Affairs portfolio was designed to allow Rudd greater control over foreign policy decisions and keep the 'big gigs' for himself. In fact, if anything Rudd has become too involved in the micro-management and nitty gritty of running Australia's foreign policy, objecting to personnel decisions being made at the Department of Foreign Affairs and Trade (DFAT). ${ }^{49}$

Rudd needed to be careful not to overload the DFAT with ideas on Asian union. DFAT suffered budget cuts throughout the Howard years. And yet even as Rudd has demanded that DFAT adopt an Asian regional focus and make other adjustments ${ }^{50}$, not only is no new money is coming forward, but some further cuts are already announced. 
DFAT staff numbers in Canberra declined by nearly 20 per cent since 1986, while overseas staffing has contracted more rapidly still. ${ }^{51}$ Moreover, only a quarter of these have foreign language skills. Within the DFAT, a certain fatigue is setting in. Ministerial level leadership is also lacking, neither Smith (nor Downer before him) were as dynamic as Evans. But where Downer was close to his Prime Minister, Smith is less so. Moreover, Smith and the Trade Minister have bad political blood between them, further dividing the portfolio. It hardly seems an adequate base to launch an attempt at regional institution building, certainly not compared to the Hawke years.

At the same time, there have been important changes within Australia's political economy and society at large. During the prior ALP administration from 1983-1996, Australia looked primarily to Japan as the largest export market for its goods. At the same time, there were tensions about Japanese investment in Australia, especially property market. This has now changed. China is now the largest market for Australian goods. At the same time, its investment in Australia is becoming political, with the Rio Tinto bid by Chinalco failing in June 2009. China is buying up shares in Rio Tinto and other Australian companies to improve energy security, not for the Australian national interest. (Herald etc.)

Societal changes also count. Chinese immigration to Australia has expanded. In fact, in 2001 Australia's census shows that after 50 years the Chinese language displaced Italian as the second language of Sydney. Both in the Prime Minister Rudd's electoral seat of Griffith, and in Howard's seat of Bennelong there is a growing number ethnic Chinese. On the flip side, with the reversion of Hong Kong there are now more Australians in China than in Japan, by a factor of five at least. And in 2005, a Lowy institute poll indicated Australian attitudes towards the US foreign policy were more worried that toward China. ${ }^{52}$

\section{(3) External factors: World Financial Crisis}

Rudd also faced strong external pressures to re-orientate Australia to Asia, and towards cooperation in multilateral organisations. The first of these external factors is the Global Financial Crisis, which some have called disparagingly 'Rudd's War'. The GFC not only demonstrated the weakness of the US financial system with the failure of the Lehmann Brothers, but seeded doubts about the strength of its economy as a whole as now General Motors is threatened with bankruptcy. This crisis has shown that America has overstretched its empire during the Bush administration, and put in question the ability of the United States to continue to underwrite the security order in East Asia. Japan too is suffering from the crisis, with its economic growth dependent on exports, chiefly to the United States, and Japanese manufacturers and workers are feeling the pinch.

At the same time, however, the crisis has been a relatively 'good one' for China, 
with China's image as a leader improved even as the images of the United States and Japan have suffered. Even before the crisis, Rudd argued that China needed to be better integrated into global governance architecture, using the term of 'important stock holder' rather than the US version 'responsible stake holder'. As the crisis has unfolded, Rudd sought to use the G20 meeting to boost Australia's presence. The potential for an Asian 7 (if Australia and the ASEAN Chair are included) caucus bloc within the G20 would be a useful innovation for Australia, if it comes about.

But in addition to the immediate crisis which is accelerating the process, Australia is still attempting to manage its influence in an Asian region in which the balance of power is changing. It has been this fundamental shift in the balance of powers which has driven the APC concept. Rudd talked about the need to manage security cooperative if a security dilemma, or arms race, is to be avoided.

In fact, the Government's assessment of the balance of power was made clear in the 2009 Defence White Paper. Indeed, the Minister's preface notes simply: 'But the biggest changes to our outlook over the period have been the rise of China, the emergence of India and the beginning of the end of the so-called unipolar moment; the almost twodecade-long period in which the pre-eminence of our principal ally, the United States, was without question'. And China is not identified as a threat formally in the document; it is clear that Australia's decision to strengthen its maritime power was made in the light of the emergent Chinese blue-water navy and a possibly less important role for the United States.

\section{The Effectiveness and Limitations of the ASEAN+3 Framework}

The creation of ASEAN+3 means that decision makers in China, Japan, South Korea and ASEAN countries agreed on identifying their own countries with 'East Asia' and on advancing cooperation and coordination under the tremendous crisis destroying the myth of 'East Asian Miracle'. Since then, 'East Asian' regional cooperation in ASEAN+3 has been attempted in various specific fields. As a result, ASEAN+3 is trying to construct a new political and economic mechanism in East Asia, beyond the response to the crisis. ASEAN +3 is one of the ASEAN regime, and it might be replaced by a genuine East Asian regional framework.

Since the establishment of the ASEAN+3, a variety of issues have been discussed. In 1998 and 1999, financial ministers' meetings were held. Economic ministers' meetings, foreign ministers' meetings, and agriculture and fishery ministers' meetings, energy ministers' meetings have also held. When the SARS epidemic spread in East Asia, health ministers gathered, recognising it as a new crisis for the region.

No matter how rapidly the ASEAN+3 has developed, it has had some limitations. 
First of all, the ASEAN+3 is dependent on the ASEAN regime. The institutionalisation of the ASEAN+3 framework has advanced by using the ASEAN framework. Meetings of ASEAN +3 are held at ASEAN's invitation to China, Japan and South Korea to join when ASEAN meetings are held. For example, the ASEAN+3 Summit is held when ASEAN Summit is held. In addition, several 'ASEAN+1' Summit meetings, that is ASEAN-China, ASEAN-Japan, ASEAN-South Korea, are also held at the same time. In short, ASEAN+3 is institutionally part of ASEAN regime even though East Asian countries are developing the habit to gather to discuss their regional issues.

Moreover, the ASEAN +3 is one of various regional cooperation frameworks covering East Asia. For instance, the Asia Pacific Economic Cooperation (APEC), the ASEAN Regional Forum (ARF), and the ASEM have initiated a variety of projects that have been linked and supplemented each other. Networks among these regional frameworks have been constructed in each specific field.

The orientations of East Asian regionalism do not converge in just the ASEAN+3 framework, as shown in the process of cooperation of Asian bond market. Regional cooperation based on ASEAN+3 is conspicuous, but only part of various and incipient East Asian regionalism. 'East Asia' is transforming from a mere area to a 'region' that has various cooperation, coordination and linkages. Nonetheless, besides the trends related to the ASEAN+3 framework, some other trends that will affect the establishment of 'East Asian' region have been taking place.

First of all, bilateral FTAs between some countries in East Asia and some others in and outside East Asia may affect the solidarity of 'East Asia' and some others in and outside East Asia may affect the solidarity of 'East Asia' and 'East Asian' regional identity. For instance, Japan signed an FTA with Singapore in January 2002, and has been examining the feasibility and viability of an FTA with Korea and has been negotiating with Mexico. Among ASEAN countries, Singapore and Thailand enthusiastically attempt to explore FTAs with countries in and outside East Asia. Singapore signed FTAs with New Zealand, Japan (January 2002), Australia (November 2002) and the United States (May 2003). It expects to expand a pact with New Zealand to Chile. ${ }^{53}$ Thailand concluded FTA with Bahrain in January 2003, and is seeking to explore bilateral FTAs both with some of East Asian countries, China and Japan, and those outside it. Malaysia, which had been reluctant for a bilateral FTA, changed its stance and indicated that it is open to having bilateral FTAs with the United States, Japan and China.

Second, the prevalence of FTAs in East Asia, and between East Asia and other areas as well, is partly based on pragmatism of such countries to link with each of their countries' major trading partners. Further, it indicates that some East Asian countries, especially Singapore and Thailand, are seeking to strengthen their positions in the global arena beyond 
Asia, through promoting FTAs with countries outside the region. It is difficult to judge whether bilateral FTAs inevitably hamper deepening regionalism in East Asia. Probably, as ASEAN+X-type FTAs, bilateral FTAs among East Asian countries will entail encouraging regionalism in East Asia. On the other hand, however, bilateral FTAs between individual East Asian countries and counties outside have made an exclusive 'East Asia', such as an 'East Asian Bloc', less feasible.

Finally, the posture of the United States towards East Asian regionalism has significantly affected and will affect East Asian regionalism. American attitudes toward developing East Asian regionalism at present are, at least on the surface, not as antagonistic as they were in the past, as demonstrated in such cases as EAEG/EAEC and an Asian Monetary Fund (AMF). The United States even proposed the Enterprise for ASEAN Initiative (EAI) in October 2002, offering the prospect of FTAs between the United States and ASEAN countries. Proposal of EAI reflected US eagerness to tighten relationship with ASEAN countries. In addition to the expectation of economic interests in Southeast Asia the concern with anti-terrorist cooperation led the United States to this proposal. After the terrorist attacks of 11 September 2001, the United States has tightened security cooperation between ASEAN countries. For example, in August 2002, the United States and ASEAN declared to take joint action against terrorism. Such a trend has accelerated after the terrorist blast in Bali in October 2002. Australia joined the United States in intensifying security cooperation with ASEAN countries.

\section{Concluding Remarks}

Since the 1990s, a number of bilateral or regional FTAs have been concluded or are under negotiation or examination. Needless to say, FTAs attempt to minimise barriers and deepen economic linkages among member countries in order to increase trade and investment among them and to increase economic efficiency and to create a larger market than the internal markets of individual members. However, motivations for concluding FTAs do not stem only from expectations for genuine economic benefits. It sometimes comes from desires to tighten political ties with specific countries. The development of East Asian regionalism has been or will be strongly affected by various trials of the individual East Asian countries to tighten economic and political ties with each other or with countries outside East Asia, by concluding FTAs.

It was remarkable that East Asian regionalism-regionalism which attempted to unite Japan, China Korea and ASEAN countries together-emerged and developed in a short period. For, these countries were so diverse in political, economic and social character except adopting capitalism or quasi-capitalism economically. Besides, memories of Japan's dominance and its atrocities still remained in some East Asian countries. As mentioned 
above, the confidence of East Asian countries stemmed from the 'East Asian Miracle', and the shared spirit to counter the pressures from the United States and Europe led to the emergence of East Asian regionalism in the first half of 1990s. In addition, the Asian financial crisis was a strong impetus for East Asian countries advance their new regional framework, ASEAN +3 , because they needed cooperation in order to overcome damages imposed by economic crisis and to revitalise East Asian economies. Several cooperation projects have been promoted in ASEAN+3, and East Asian regionalism seems advancing even now.

What combined East Asian countries, members of ASEAN+3, as one group to promote regionalism? What made elites of East Asian counties share an East Asian regional identity? In the past, the experience of the 'East Asian Miracle' and the sufferings from the 'East Asian Meltdown' were the impetus to generate and develop East Asian regional identity. The situation, however, is changing drastically. The future of East Asia regionalism has become amorphous because of complicated and new trends that the paper depicted.

On the basis of the increasing complexity of East Asian regionalism, there are three main desires among East Asian countries. One is the desire of each country in East Asia to survive the huge waves of globalisation. Its character is based on pragmatism. A second desire is to construct the regional mechanism for financial, economic, and political cooperation and consultation that enhances Asian identity, and that makes East Asia less dependent on the United States and Europe. A third desire shared mainly among Japan, China and the advanced countries in ASEAN is to take the initiative to construct a new East Asia. Those three desires not only coexist but are interrelated with each other, and will determine the course of complicated trends listed above.

Japan, one of the important actors that constitutes a triangular relationship in East Asia, has been encouraging the development of East Asian regionalism in the economic arena. Korea took a strong initiative in managing the economic issues, and tried to convert ASEAN+3 into a genuine regional framework. Korea is proposing a FTA with ASEAN. Japan and Korea have been seeking to conclude the FTA. The entry of Korea would transform the triangular relationship into quadrilateral one. Besides, the tripartite framework for cooperation and consultation has advanced between Japan, China and Korea, as the tripartite Summit in October 2003 adopted the declaration that the three countries enhance the security dialogue and cooperate for containing nuclear proliferation, especially with regard to threat from North Korea's WMD. The relationship between Japan and Korea is developing beyond the legacy of the past. The future relationship between Japan and Korea will deeply influence the evolution of East Asian regionalism. 
No. 389, 2010

\section{Bibliography}

Beeson, Mark. 'Australia and Asia; the Years of Living Aimlessly'. In Southeast Asian Affairs 2001, edited by Daljit Singh. Singapore: ISEAS, 2001.

Bisley, Nick. 'Australia and APEC in the Twenty-First Century: Love, Lost and Found.' In APEC and the Search for Relevance: 2007 and Beyond, edited by John Ravenhill. Canberra: ANU Press, 2006.

Brenchley, Fred. 'The Howard Defence Doctrine.' Bulletin, 21 September 1999, pp22-24. Clark, Michael. 'Issues in Australian Foreign Policy: July to December 2007.' Australian Journal of Politics and History 54, no. 2 (2008).

Cotton, James. 'Asian Regionalism and the Australian Policy Response in the Howard Era'. Journal of Australian Studies 32, no. 1 (2008).

Cotton, James, and John Ravenhill. 'Australia's Engagement with Asia'. In Seeking Asian Engagement; Australia in World Affairs, 1991-1995, edited by James Cotton and John Ravenhill. Melbourne: Oxford University Press Australia, 1997.

Department of Defence. 'Australia's Strategic Policy'. Canberra: Department of Defence, 1997.

Department of Foreign Affairs and Trade. In the National Interest Australian Foreign and Trade Policy White Paper. Canberra: Department of Foreign Affairs and Trade, 1997. - Advancing the National Interest: Australian Foreign and Trade Policy White Paper. Canberra: Department of Foreign Affairs and Trade, 2003.

Dobell, Graeme. 'Asia Community; Rudd Moves On.' The Lowy Inquirer (2009).

Dodd, Mark. 'Support Grows for Asia-Pacific Push.' The Australian, 22 April 2009.

Downer, Alexander. 'Australia's Place in the World.' In Address to the NSW Division of the Liberal Party. Sydney, 1996.

—_. 'China; Asia Leaders Forum - Mr. Downer's Opening Speech.' 2000.

Flitton, Daniel. 'PM Blocks Diplomatic Posting.' The Age, 25 May 2009.

Jones, David Martin. 'Australia, China and the Region'. In Australian Foreign Policy in the Age of Terror, edited by Carl Ungerer. Sydney: UNSW Press, 2008.

Leaver, Richard. 'Issues in Australian Foreign Policy; January to June 2008.' Australian Journal of Politics and History 54, no. 4 (2008).

McDougall, Derek. 'Australia and the Asia-Pacific Security Regional; from Hawke to Keating to Howard.' Contemporary South East Asia 23, no. 1 (2001).

Milner, Anthony. 'The Rhetoric of Asia.' In Seeking Asian Engagement; Australia in World Affairs, 1991-1995, edited by James Cotton and John Ravenhill. Melbourne: Oxford University Press Australia, 1997.

Ravenhill, John. 'Cycles in Middle Power Activism: Constraint and Choice in Australian and 
Asia Pacific Economic Papers

Canadian Foreign Policies.' Australian Journal of International Affairs 52, no. 3 (1998).

Roggeveen, Sam. 'More Reactions to Rudd's Big Idea ' the Lowy Institute, www.lowvinterpreter.org.

Scott, Keith. Gareth Evans. Sydney: Allen Unwin, 1999.

Sheridan, Greg. 'Asia Pacific Joint Security Statement Takes Aim at China's Military BuildUp.' The Australian, 9 March 2009.

Soesastro, Hadi. 'Kevin Rudd's Architecture for the Asia Pacific.' eastasiaforum.org.

Ungerer, Carl. 'Australia's Place in the International System.' In Australian Foreign Policy in the Age of Terror, edited by Carl Ungerer. Sydney: UNSW Press, 2008.

Viviani, Nancy. 'Australia and Southeast Asia.' In Seeking Asian Engagement; Australia in World Affairs, 1991-1995, edited by James Cotton and John Ravenhill. Melbourne: Oxford University Press Australia, 1997.

Wesley, Michael. The Howard Paradox; Australian Diplomacy in Asia 1996-2006. Sydney: ABC Books, 2007. 


\section{Endnotes}

1 Thomas Wright, "Toward Effective Multilateralism: Why Bigger is Not Always Better," The Washington Quarterly, 32-33, July 2009, pp. 163-80. Also, see David A. Lake, Entangling Relations: American Foreign Policy in Its Century (Princeton: Princeton University Press, 1999), chaps. 6-8.

2 Carl Ungerer, 'Australia's Place in the International System', in Australian Foreign Policy in the Age of Terror, ed. Carl Ungerer (Sydney: UNSW Press, 2008). pp28-9.

$3 \quad$ Ibid. p30.

4 Woolcott was Secretary of the Department of Foreign Affairs and Trade 1998-92 and former Ambassador to Indonesia and the United Nations in New York.

5 John Ravenhill, 'Cycles in Middle Power Activism: Constraint and Choice in Australian and Canadian Foreign Policies,' Australian Journal of International Affairs 52, no. 3 (1998). p315.

6 James Cotton and John Ravenhill, 'Australia's Engagement with Asia,' in Seeking Asian Engagement; Australia in World Affairs, 1991-1995, ed. James Cotton and John Ravenhill (Melbourne: Oxford University Press Australia, 1997). p3

7 Derek McDougall, 'Australia and the Asia-Pacific Security Regional; from Hawke to Keating to Howard,' Contemporary South East Asia 23, no. 1 (2001). p85.

$8 \quad$ Keith Scott, Gareth Evans Sydney: Allen Unwin, 1999. p234.

9 Alexander Downer, 'Australia's Place in the World,' in Address to the NSW Division of the Liberal Party (Sydney: 1996).

10 'In the National Interest,' in Australian Foreign and Trade Policy White Paper (Canberra: Department of Foreign Affairs and Trade, 1997). pp37, 40 'the government does not regard regional approaches to security as a replacement for strong bilateral security arrangements'

11 Michael Wesley, The Howard Paradox; Australian Diplomacy in Asia 1996-2006 (Sydney: ABC Books, 2007).12-13, containing the famous reference to the claws of the crabs.

12 Ibid.88-9, 119-20. Downer became dismissive of 'emotional' regionalism after failed to get in to ASEM.

13 McDougall, 'Australia and the Asia-Pacific Security Regional; from Hawke to Keating to Howard.' p94.

14 Ibid.94-6.

15 Fred Brenchley, 'The Howard Defence Doctrine,' Bulletin, 21 September 1999.

16 Alexander Downer, 'China; Asia Leaders Forum - Mr. Downer's Opening Speech,' (2000). At the Beijing Forum in April 2000, however, Downer contradicted this view and caused a stir by undiplomatically noted that Australia was uninterested in Asia's 'emotional regionalism', only its practical side.

17 The US Defense Secretary attempted to defuse the tensions between Australia and Southeast Asia by saying 'Australia is not the US's deputy sheriff perversely increasing the perception that Australia was in fact an American lackey.

18 '...it stands to reason that if you believe that somebody was going to launch an attack against your country, either of a conventional kind of a terrorist kind, and had the capacity to stop it and there was no alternative other than to use that capacity then of course you would use it'.

19 And while the 2005 version of the $A N S$ noted more positively 'the effectiveness of ASEAN 
as a force for change and resolution of regional issues' (and the role of ARF for CBMs), the 2007 Defence update mentions these organisations only in passing. James Cotton, 'Asian Regionalism and the Australian Policy Response in the Howard Era,' Journal of Australian Studies 32, no. l (2008). pl21.

20 'Advancing the National Interest,' in Australian Foreign and Trade Policy White Paper (Canberra: Department of Foreign Affairs and Trade, 2003). p7.

21 In fact these Quad talks were to be strategic talks, presumably aimed at China. But when Abe proposed such a strategic angle to President Bush he was cut off by SS Rice fearing China's response. Also see, Michael Clark, 'Issues in Australian Foreign Policy: July to December 2007,' Australian Journal of Politics and History 54, no. 2 (2008).

Wesley, The Howard Paradox; Australian Diplomacy in Asia 1996-2006.127-8.

Ungerer, 'Australia's Place in the International System.' 34-5.

Cotton, 'Asian Regionalism and the Australian Policy Response in the Howard Era'.122

Ibid. pl20.

Malaysia, Thailand, Philippines, Indonesia Brunei, East Timor, Cambodia, plus agreement with PNG, India, Pakistan, Turkey and Fiji.

However, his actual practice is somewhat different, nor does it seem he was very intellectual about his conservatism, see Wesley for more.

Wesley, The Howard Paradox; Australian Diplomacy in Asia 1996-2006. 54.

Mark Beeson, 'Australia and Asia; the Years of Living Aimlessly,' in Southeast Asian Affairs 2001, ed. Daljit Singh (Singapore: ISEAS, 2001).

Anthony Milner, 'The Rhetoric of Asia,' in Seeking Asian Engagement; Australia in World Affairs, 1991-1995, ed. James Cotton and John Ravenhill (Melbourne: Oxford University Press Australia, 1997).33.

31 Nancy Viviani, 'Australia and Southeast Asia,' in Seeking Asian Engagement; Australia in World Affairs, 1991-1995, ed. James Cotton and John Ravenhill (Melbourne: Oxford University Press Australia, 1997).164.

McDougall, 'Australia and the Asia-Pacific Security Regional; from Hawke to Keating to Howard.' 86. For instance, Samuel Huntington calls Australia a 'torn country', with an identity crisis.

Involving the off-shore processing in foreign countries (Nauru and Papua New Guinea) of asylum seekers intercepted on boats headed fro Australia.

Ibid. 125

David Martin Jones, 'Australia, China and the Region', in Australian Foreign Policy in the Age of Terror, ed. Carl Ungerer (Sydney: UNSW Press, 2008).194.

Wesley, The Howard Paradox; Australian Diplomacy in Asia 1996-2006.12-14, Development Important Finance Facility (DIFF) tied aid loan scheme scandal, Australia called the 「蟹の鋏」in the People's Daily.

\section{Ibid.73}

Japan had to changes its domestic laws to do so

Richard Leaver, 'Issues in Australian Foreign Policy; January to June 2008,' Australian Journal of Politics and History 54, no. 4 (2008). 
41 Ibid.

42 Hadi Soesastro, 'Kevin Rudd's Architecture for the Asia Pacific', eastasiaforum.org.

43 Leaver, 'Issues in Australian Foreign Policy; January to June 2008.'

44 Sam Roggeveen, 'More Reactions to Rudd's Big Idea', The Lowy Institute, www.lowyinterpreter.org.

45 Graeme Dobell, 'Asia Community; Rudd Moves On,' The Lowy Inquirer (2009).

46 Mark Dodd, 'Support Grows for Asia-Pacific Push,' The Australian, 22 April 2009.

47 The security agreement is interesting as it contains the same language that China protested against in the Japan-Australia security agreement. In other words, it hails the shared values of democracy, intelligence sharing and locates Korea and Australia as US allies. Greg Sheridan, 'Asia Pacific Joint Security Statement Takes Aim at China's Military Build-Up,' The Australian, 9 March 2009.

48 Soesastro, 'Kevin Rudd's Architecture for the Asia Pacific.'

49 Daniel Flitton, 'PM Blocks Diplomatic Posting,' The Age, 25 May 2009.

50 Cotton and Ravenhill, 'Australia's Engagement with Asia'. 7

51 Ungerer, 'Australia's Place in the International System'. 50

52 Cotton, 'Asian Regionalism and the Australian Policy Response in the Howard Era.'

53 The Straits Times, 28 October 2002. 
Asia Pacific Economic Papers

\section{Previous Asia Pacific Economic Papers}

388 How Does a Decrease in Oil Production Affect the World Economy? Naobiko Yahaba, 2010

387 Internal Promotion and the Effect of Board Monitorin: a Comparison of Japan and the United States Meg Sato, 2010

386 Interaction between trade, conflict and cooperation: the case of Japan and China Shiro Armstrong, 2010

385 Japanese Aid as a prerequisite for FDI: the case of Southeast Asian countries Séverine Blaise, 2009

384 Insular Decision-making in the Board Room: Why Boards Retain and Hire Sub-Standard CEOs Meg Sato, 2009

383 How does Financial System Efficiency Affect the Growth Impact of FDI in China? Ying $X u, 2009$

382 A Tale of Pork Prices: Evasion and Attenuation of a Japanese Tariff Kazuki Onji, 2009

381 Are the East Asian Currencies Still Misaligned? An Analysis Based on Absolute ppp-Income Relationship using Panel Data

Taizo Motonishi, 2009

380 Is Foreign Aid a Vanguard of Foreign Direct Investment? A Gravity-Equation Approach Hidemi Kimura and Yasuyuki Todo, 2009

379 Rain, Elections and Money: The Impact of Voter Turnout on Distributive Policy Outcomes in Japan Yusaku Horiuchi and Jun Saito, 2009

378 Japanese FDI in China: determinants and performance Shiro Armstrong, 2009

377 Expansion Abroad and Jobs at Home: Evidence from Japanese Multinational Enterprises Nobuaki Yamashita and Kyoji Fukao, 2009

376 Should Australia Encourage Developing Countries to Adopt Competition Laws? Henry Ergas, 2008

375 Will New Trends in Foreign Direct Investment Change the Structure of Intra-industry Trade between China and Japan?

Tao Tao, 2008

374 Competition Policy in ASEAN: Case studies

Johannah Branson, 2008

373 Can the New Antimonopoly Act Change the Japanese Business Community? The 2005 Amendment to Antimonopoly Act and Corporate Compliance.

Kazukiyo Onishi, 2008

372 Immunising future trade against protectionists: preventing the emergence of more sensitive sectors Andrew Elek, 2008

371 Tax law asymmetries and income shifting: evidence from Japanese Capital KEIRETSU Kazuki Onji and David Vera, 2008

370 The response of firms to eligibility thresholds: evidence from the Japanese value-added tax Kazuki Onji, 2008

369 China and East Asian Energy: Prospects and Issues Vol. 1 \& 11

Peter Drysdale, Kejun Jiang and Dominic Meagher, 2008

368 Measuring trade and trade potential

Shiro Armstrong, 2007 
Annual subscription rate for up to eight issues:

Individuals A $\$ 65.00$ (includes GST) A $\$ 60$ (overseas)

Institutions A $\$ 110.00$ (includes GST) A \$100 (overseas)

\title{
Cost for single issues:
}

\author{
A $\$ 16.50$ (includes GST) A $\$ 15.00$ (overseas) \\ A $\$ 10.00$ (Students) \\ No postage required within Australia
}

Available from:

Centre Administrator

Australia-Japan Research Centre

Crawford School of Economics and Government

ANU College of Asia and the Pacific

The Australian National University

Canberra ACT 0200, Australia

Facsimile: (61 2) 61258448

Telephone: (61 2) 61253780

Email: ajrc@anu.edu.au

URL: http:/www.crawford.anu.edu.au 